\title{
Relationship between Anxiety Level to the Increased Pulse Rate and Blood Pressure of Pre-Major Operation Patients
}

\author{
${ }^{1}$ Suharto, ${ }^{\mathbf{2}}$ Erni Nuryanti, ${ }^{3}$ Ronal Tolkhah, ${ }^{\mathbf{T}}$ Tavip Indrayana \\ ${ }_{1,2,3,4}$ Nursing Department, Politeknik Kesehatan Kemenkes Semarang
}

\begin{abstract}
:
Background: Response to surgery will be different for each person because the responds to the operation are different. Anxiety is an emotional response to the subjective judgment, which is influenced by the subconscious and is not precisely known for the cause.
\end{abstract}

Objective: The purpose of the study is to find out the relationship between the anxiety level with the increase of the pulse and the increase of blood pressure.

Method: This research involves patients treated in General Hospital dr. R. Soetijono, Blora, Central Java, Indonesia from August to October 2016. Data were analyzed with Chi-Square.

Result: The result of this research is $p$ value (0.001) smaller than $\alpha(0.05)$ meaning there is a relation between anxiety level with an increase of pulse and $p$ value $(0.000)$ less than $\alpha(0,05)$ meaning there is an association between level of concern with an increase in blood pressure.

Conclusion: There is a relationship between anxiety levels with the elevated pulse and blood pressure in patients with primary surgery.

Keywords: Anxiety, pulse, blood pressure

\section{INTRODUCTION}

Surgery is one of the medical problem solving done by doctors to treat difficult or impossible conditions to be cured only with simple medicines. The remedial action is also a stressful experience for almost all patients because of the dangerous possibilities that can happen that will endanger the patient. Surgery is one form of medical therapy that the body can bring stress because of threats to the body, integrity and the soul of a person. Every individual sees that surgery is a big event that will bring fear and anxiety.

Anxiety is an emotional response to the subjective judgment, which is influenced by the subconscious and is not known accurately the cause (Ernawati, 2009). Anxiety will cause response "fight or flight." Flight is the body's isotonic reaction to escape, where there is increased adrenaline secretion into the blood circulation that will cause increased heart rate and systolic blood pressure. On the other hand, the fight is an aggressive reaction to attack causing adrenaline secretion; rennin-angiotensin react that blood pressure will increase both in systolic and diastolic. The excessive amount of adrenaline flow causes blood pressure to rise (Faisal Idrus, 2006).

Based on the phenomenon, the authors are interested in conducting research on "the relationship between anxiety levels with increased pulse and blood pressure in pre major surgery patients.

\section{Materials AND Methods}

The independent variables in this study are the level of anxiety patients pre-major surgery and dependent variables are increased pulse and elevated blood pressure in adult patients.

The type of research conducted is an associative study with the aim to determine the relationship of the level of anxiety with increased pulse and increased blood pressure. The study was carried out on August to October 2016 in dr. R. Soetijono Hospital, Blora, Central Java, Indonesia. The population is all 27 patients who will undergo surgery at the particular hospital. Univariate analysis is used to determine the frequency and proportion of each variable. Chi-Square test is used to find out the relationship between independent variable and dependent variable. 


\section{RESULTS AND DISCUSSIONS}

\subsection{Results}

The characteristics of respondents are depicted in the following table.

Table1. Characteristics of Respondents

\begin{tabular}{|c|c|c|}
\hline Variables & Numbers & Percentage $(\%)$ \\
\hline Ages & & \\
\hline$\leq 30$ years & 9 & 33.3 \\
\hline $31-40$ years & 7 & 25.9 \\
\hline $41-50$ years & 4 & 14.8 \\
\hline 51-60 years & 1 & 3.7 \\
\hline$>60$ years & 6 & 22.2 \\
\hline Total & 27 & 100 \\
\hline Gender & & \\
\hline Men & 11 & 40.7 \\
\hline Women & 16 & 59.3 \\
\hline Total & 27 & 100 \\
\hline Educational Background & & \\
\hline Elementary & 12 & 44.4 \\
\hline Junior High & 7 & 25.9 \\
\hline Senior High & 5 & 18.5 \\
\hline Degree & 3 & 11.1 \\
\hline Total & 27 & 100 \\
\hline Operation Record & & \\
\hline $\mathrm{NO}$ & 25 & 92.6 \\
\hline YES & 2 & 7.4 \\
\hline Total & 27 & 100 \\
\hline Level of Anxiety & & \\
\hline Mild & 13 & 48.1 \\
\hline Moderate & 14 & 51.9 \\
\hline Total & 27 & 100 \\
\hline
\end{tabular}

Table 1 shows most patients aged $\leq 30$ years. Most of the patients are female. Patients with elementary education as many as 12 patients $(44.4 \%)$ and bachelor degree as many as three patients $(11.1 \%)$. This composition indicates that most of the major preoperative patients have primary school education. Most of the patients had never experienced previous surgery (92.6\%), and the anxiety level was experiencing moderate anxiety (51.9\%).

The level of anxiety based on ages is observable on the following table.

Table2. The level of anxiety based on ages

\begin{tabular}{|l|l|c|c|c|c|c|}
\hline \multirow{2}{*}{ Ages } & \multicolumn{2}{|l|}{ Anxiety } & \multicolumn{2}{|c|}{ Total } \\
\cline { 2 - 6 } & \multicolumn{2}{|c|}{ Mild } & \multicolumn{2}{|c|}{ Moderate } & & \\
\hline$\leq 30$ years & 4 & $(14.8 \%)$ & 5 & $(18.5 \%)$ & 9 & $(33.3 \%)$ \\
31-40 years & 5 & $(18.5 \%)$ & 2 & $(7.4 \%)$ & 7 & $(25.9 \%)$ \\
41-50 years & 2 & $(7.4 \%)$ & 2 & $(7.4 \%)$ & 4 & $(14.8 \%)$ \\
51-60 years & 0 & $(0 \%)$ & 1 & $(3.7 \%)$ & 1 & $(3.7 \%)$ \\
$>$ 60 years & 2 & $(7.4 \%)$ & 4 & $(14.8 \%)$ & 6 & $(22.2 \%)$ \\
\hline Total & 13 & $(48.1 \%)$ & 14 & $(51.9 \%)$ & 27 & $(100 \%)$ \\
\hline
\end{tabular}

Table 2 shows that most $31-40$ years of age experience mild anxiety $(18.5 \%)$ and age $\leq 30$ years experienced moderate anxiety $(18.5 \%)$.

Table3. Anxiety level by Gender

\begin{tabular}{|c|c|c|c|c|c|c|}
\hline \multirow{2}{*}{ Gender } & \multicolumn{4}{|c|}{ Anxiety } & \multicolumn{2}{|c|}{ Total } \\
\cline { 2 - 5 } & \multicolumn{3}{|c|}{ Mild } & \multicolumn{2}{|c|}{ Moderate } & \multicolumn{2}{c|}{} \\
\hline Men & 5 & $(18.5 \%)$ & 6 & $(22.2 \%)$ & 11 & $(40.7 \%)$ \\
Women & 8 & $(29.6 \%)$ & 8 & $(29.6 \%)$ & 16 & $(59.3 \%)$ \\
\hline Total & 13 & $(48.1 \%)$ & 14 & $(51.9 \%)$ & 27 & $(100 \%)$ \\
\hline
\end{tabular}

Table 3 shows that patients female patients experienced mild anxiety (29.6\%), as well as moderate (29.7\%). This condition suggests that most stress occurs in female patients. 
Relationship between Anxiety Level to the Increased Pulse Rate and Blood Pressure of Pre-Major Operation Patients

Table4. Anxiety Level Based on Education

\begin{tabular}{|c|c|c|c|c|c|c|}
\hline \multirow[t]{2}{*}{ Education } & \multicolumn{4}{|c|}{ Anxiety } & \multirow{2}{*}{\multicolumn{2}{|c|}{ Total }} \\
\hline & \multicolumn{2}{|c|}{ Mild } & \multicolumn{2}{|c|}{ Moderate } & & \\
\hline Elementary & 7 & $(25.9 \%)$ & 5 & $(18.5 \%)$ & 12 & $(44.4 \%)$ \\
\hline Junior High & 1 & $(3.7 \%)$ & 6 & $(22.2 \%)$ & 7 & $(25.9 \%)$ \\
\hline Senior High & 3 & $(11.1 \%)$ & 2 & $(7.4 \%)$ & 5 & $(18.5 \%)$ \\
\hline Degree & 2 & $(7.4 \%)$ & 1 & $(3.7 \%)$ & 3 & $(11.1 \%)$ \\
\hline Total & 13 & $(48.1 \%)$ & 14 & $(51.9 \%)$ & 27 & $(100 \%)$ \\
\hline
\end{tabular}

Table 4 shows that seven patients $(25.9 \%)$ with primary school education experienced mild anxiety, and six patients with secondary school education (22.2\%) experienced moderate anxiety.

Table5. Anxiety level based on surgery record

\begin{tabular}{|c|c|c|c|c|c|c|}
\hline \multirow[t]{2}{*}{ Surgery Record } & \multicolumn{4}{|c|}{ Anxiety } & \multirow{2}{*}{\multicolumn{2}{|c|}{ Total }} \\
\hline & \multicolumn{2}{|c|}{ Mild } & \multicolumn{2}{|c|}{ Moderate } & & \\
\hline No & 11 & $(40.7 \%)$ & 14 & $(51.9) \%$ & 25 & $(92.6 \%)$ \\
\hline Yes & 2 & $(7.4 \%)$ & 0 & $(0 \%)$ & 2 & $97.4 \%)$ \\
\hline Total & 13 & $(48.1 \%)$ & 14 & $(51.9 \%)$ & 27 & $(100 \%)$ \\
\hline
\end{tabular}

Table 5 shows that the majority of patients who had not previously had surgery experienced mild anxiety $(40.7 \%)$, and moderate $(51.9 \%)$. Furthermore, 18 patients $(66.7 \%)$ had an elevated pulse.

Table6. Relationship of anxiety level with patient's blood pressure

\begin{tabular}{|c|c|c|c|c|c|}
\hline & \multicolumn{2}{|c|}{ Blood Pressure } & & \\
\hline Anxiety & Not Increased & Increased & Total Count & $X^{2}$ & P value \\
\hline Mild & $9(33.3 \%)$ & $4(14.8 \%)$ & $13(48.1 \%)$ & 14.538 & 0.000 \\
Moderate & $0(0 \%)$ & $14(51.9 \%)$ & $14(51.9 \%)$ & & \\
\hline Total & $9(33.3 \%)$ & $18(66.7 \%)$ & & & $27(100 \%)$ \\
\hline
\end{tabular}

Table 6 shows the level of moderate anxiety, there is an increase in blood pressure more $(51.9 \%)$ compared with mild anxiety level (14.8\%). The results obtained statistically using Chi Square test results obtained $\mathrm{X}^{2}(14.538)$ and $\mathrm{p}$ - value (0.000) smaller than $\alpha(0.05)$ meaning there is a relationship between anxiety levels with increased blood pressure.

Table7. Relationships of anxiety levels with the patients' pulse rate

\begin{tabular}{|c|c|c|c|c|c|}
\hline & \multicolumn{2}{|c|}{ Blood Pressure } & & \multicolumn{1}{|c|}{ P value } \\
\hline Anxiety & Not Increased & Increased & Total Count & $X^{2}$ & \multirow{2}{*}{0.001} \\
Mild & $9(33.3 \%)$ & $4(14.8 \%)$ & $13(48.1 \%)$ & 15.600 & $0.001 .9 \%)$ \\
\hline Moderate & $0(0 \%)$ & $14(51.9 \%)$ & $14(51.9 \%)$ & & $27(100 \%)$ \\
\hline
\end{tabular}

Table 7 shows at the level of moderate anxiety that there is an increase in pulse rate $(51.9 \%)$ compared with mild anxiety level (14.8\%). This condition is not different from the result of blood pressure. The result of statistical analysis using Chi Square test is $X^{2}(15.600)$ and p-value (0.001) less than $\alpha(0.05)$ indicating there is a relationship between anxiety levels with increased pulse rate.

\subsection{Discussion}

The results showed that most patients with major surgery had increased blood pressure and pulse rate $(66.7 \%)$.

Increased blood pressure is caused by anxiety in the facing of surgery. Increased blood pressure and pulse also varied. If the blood pressure and pulse increase very high, then before surgery must be given tension-reducing drugs and conducted supervision. If blood pressure and pulse remain high and do not go down then surgery is delayed until blood pressure and pulse normal again. According to Ernawati (2009), the effects of anxiety at light, moderate or severe levels are the physiological response in the form of increased blood pressure and pulse. Other theories say anxiety, fear of pain and emotional stress lead to sympathetic stimulation, which enhances the frequency of blood pressure, pulse, cardiac output and peripheral vascular resistance. The effects of sympathetic stimulation result in an increase in blood pressure and pulse (Potter, 2005). 
The results of this study have been tested by Chi-Square statistical test. Based on Chi Square test results obtained p-value smaller than $\alpha(0.05)$ meaning there is a relationship between the level of anxiety with increased blood pressure. Thus if a person experiences stress, then there will be an increase in blood pressure. Also concluded there is a relationship between the level of anxiety with increased pulse. Thus if a person experiences anxiety there will be an increase in the pulse.

Anxiety is an emotional response to the subjective judgment, which is influenced by the subconscious and is not specifically known for its cause. Anxiety will lead to a "fight or flight" response. Flight is the body's isotonic reaction to escape, where there is an increase in adrenaline secretion into the blood circulation which will lead to increased heart rate and systolic blood pressure. While the fight is an aggressive reaction to attack that will cause nonadrenaline secretion, rennin-angiotensin, so that pulse and blood pressure increased both systolic and diastolic. Anxiety is ongoing excessive adrenaline flow causing pulse and blood pressure to rise (Faisal Idrus, 2014).

\section{Conclusion}

Most significant preoperative patients experience mild and moderate anxiety levels, increased pulse and increased blood pressure. There was an association between anxiety levels and elevated blood pressure in the major preoperative patients at General Hospital dr. R. Soetijono Blora, Central Java, Indonesia. Likewise, there is a relationship between anxiety levels and increased pulse in adult patients. These findings provide a view of health practitioners to take note of the patient's condition before surgery.

\section{REFERENCES}

Ernawati D. (2009), Asuhan Keperawatan Jiwa Dengan masalah Psikososial, Jakarta: Trans Info Medika.

Faisal Idrus, (2006), Anxietas dan Hipertensi. http://www.akademik.unsri.ac.id/download/journal/ files/medhas/AA- 3\%20CEMA \%28FaisalIdrus\%29ok.pdf. January 23rd, 2010.

Potter, Patricia A, , (2005), Buku Ajar Fundamental Keperawatan: Konsep, Proses, Dan Praktik, Edisi 4, EGC, Jakarta. 